\title{
Zoonotic viral infections in south africa: An overview
}

\author{
Howard Newmana ${ }^{1 *}$ and Shareef Abrahamsb ${ }^{2}$ \\ ${ }^{1}$ National Health Laboratory Service, Port Elizabeth, South Africa and Department of Pathology, Division of Medical Virology, Stellenbosch University, Cape \\ Town, South Africa \\ ${ }^{2}$ National Health Laboratory Service, Port Elizabeth, South Africa
}

\begin{abstract}
Zoonotic infections have plagued human populations for centuries. More than $60 \%$ of infectious pathogenic organisms are zoonotic in nature. Numerous vertebrate animals serve as reservoirs or amplifier hosts for these zoonoses. The factors contributing to the emergence and re-emergence of viral zoonoses include a complex interaction of factors, including environmental changes, human demographics and behaviour, and viral determinants. Zoonotic viruses are among the most important examples of emerging diseases since they can adapt rapidly to changing conditions. It is thus important that medical practitioners have some knowledge of their local zoonotic viral diseases, as this will allow for appropriate management of these conditions, most of which are often neglected.
\end{abstract}

\begin{abstract}
Abbreviations: AM: Antemortem; CCHFV: Crimean-Congo Haemorrhagic Hever Orthonairovirus; CHIKV: Chikungunya Virus; DHF/DSS: Dengue Haemorrhagic Fever/Dengue Shock Syndrome; DUVV: Duvenhage Lyssavirus; ELISA: Ezyme-Linked Immunosorbent Assay; HAI: Haemagglutination Inhibition; IFA: Immunofluorescence Assay; IgG: Immunoglobulin G; IgM: Immunoglobulin M; LBV: Lagos Bat Lyssavirus; MERS: Middle Eastern Respiratory Syndrome; MOKL: Mokola Lyssavirus; NICD: National Institute of Communicable Diseases; PCR: Polymerase Chain Reaction; PEP: Post-Exposure Prophylaxis; PM: Postmortem; PRNT: Plaque Reduction Neutralization Test; RIG: Rabies Immune Globulin; RVFV: Rift Valley Fever Phlebovirus; SARS: Severe Acute Respiratory Syndrome-Related Coronavirus; SINV: Sindbis Virus; VHF: Viral Hemorrhagic Fever; WNV: West Nile virus
\end{abstract}

\section{Introduction}

Zoonotic infections have plagued human health for centuries, and continue to be of major public health concern, as many viruses continue to emerge and re-emerge. Of the more than a thousand species of infectious organisms known to be pathogenic to humans, more than $60 \%$ are zoonotic in nature [1-3]. The high percentage of zoonoses has been ascribed to changing pressures at the human-animal interface and changing ecological factors [4]. The concept of "one health", which recognizes that human health is connected to the health of animals and the environment, and strives to foster collaboration between physicians, veterinarians and many other role players, will be important to surveil and control public health threats of a zoonotic nature [5].

Zoonoses are defined as diseases transmissible from vertebrate animals to humans [6-9]. Numerous vertebrate animals, including mammals, birds and reptiles, serve as reservoirs or amplifier hosts for viral zoonoses [6]. Based on the mode of transmission, zoonotic diseases can be classified as direct (e.g. rabies) or indirect (e.g. arthropod-borne diseases) zoonoses. Furthermore, there are two patterns of transmission of pathogens from animals to humans. In the first pattern, transmission of the pathogen to humans is a rare event but, once it has occurred, human-to-human transmission maintains the infection for a period, or permanently [10]. Examples include Simian immunodeficiency virus, Influenza A virus, and Severe acute respiratory syndrome-related coronavirus (SARS), as well as haemorrhagic fever viruses such as Ebolavirus. In the second pattern, the source of human infection is usually direct transmission or vectormediated. Wild-animal populations are the principal reservoirs and human-to-human transmission is rare. Examples include Rabies lyssavirus, West Nile virus (WNV) and the henipaviruses [10].

Emerging and re-emerging diseases are predominantly zoonotic in nature $[11,12]$. These are diseases that are newly recognised, are newly evolved, or have occurred previously but have recently increased in incidence or have expanded into a new geographical location or host range [10]. The factors contributing to emergence and re-emergence of such diseases include a complex interaction of factors such as viral determinants, environmental and ecological changes, social factors and human demographics and behaviour [11,12]. Viruses are among the most prominent examples of emerging pathogens, since they are able to adapt rapidly to changing conditions [12].

A wide variety of domestic animals and wildlife species have the potential to transmit viruses to humans. These zoonotic infections can range from clinically unapparent to fatal. Many zoonotic infections are restricted to certain geographical locations, whereas others are found worldwide. It is therefore important that medical and public-health practitioners be familiar with local common zoonotic infections, as well as being aware of the potential for imported cases. Table 1 illustrates the endemic zoonotic viral infections in South Africa.

Many of the viral zoonoses are not endemic in South Africa. However, because of the ease of international travel, the threat of

*Correspondence to: Howard Newmana, 6th Floor, NHLS Building, Cnr Buckingham Road and Eastbourne Road, Mount Croix, Port Elizabeth, South Africa, Tel: +27413956152; E-mail: howard.newman@nhls.ac.za

Key words: zoonoses, viral, arbovirus, South Africa

Received: July 02, 2018; Accepted: July 10, 2018; Published: July 15, 2018 
Table 1. Endemic zoonotic viral infections in South Africa

\begin{tabular}{|c|c|c|c|c|c|c|c|c|}
\hline \multicolumn{3}{|l|}{ Virus } & \multirow{2}{*}{$\begin{array}{l}\text { Usual } \\
\text { vertebrate host }\end{array}$} & \multirow{2}{*}{$\begin{array}{l}\text { Direct (D) or } \\
\text { Indirect (I) } \\
\text { zoonosis }\end{array}$} & \multirow{2}{*}{ Vector } & \multicolumn{2}{|c|}{ Laboratory diagnosis } & \multirow{2}{*}{ Treatment/prophylaxis } \\
\hline Family & Genus & Species & & & & Specimen & Test & \\
\hline \multirow{3}{*}{ Rhabdoviridae } & \multirow{3}{*}{ Lyssavirus } & \multirow{3}{*}{$\begin{array}{l}\text { Duvenhage } \\
\text { lyssavirus }\end{array}$} & Dogs & $\mathrm{D}$ & N/A & $\begin{array}{l}\text { AM: } \\
\text {-CSF } \\
\text {-Saliva }\end{array}$ & $\begin{array}{l}\text {-PCR } \\
\text {-PCR }\end{array}$ & $\begin{array}{l}\text { No specific treatment. } 100 \% \\
\text { mortality. Prophylaxis depends } \\
\text { on risk category (see Table 2). }\end{array}$ \\
\hline & & & $\begin{array}{l}\text { Insectivorous } \\
\text { bats }\end{array}$ & $\mathrm{D}$ & N/A & $\begin{array}{l}\text {-Nuchal biopsy } \\
\text { PM: }\end{array}$ & $\begin{array}{l}-\mathrm{PCR}+\mathrm{IFA} \\
\text {-IFA }\end{array}$ & \\
\hline & & & Cats & & $\mathrm{N} / \mathrm{A}$ & $\begin{array}{l}\text {-Brain } \\
\text {-Nuchal biopsy }\end{array}$ & -IFA + PCR & \\
\hline \multirow{2}{*}{$\begin{array}{l}\text { Nairoviridae } \\
\text { Phenuviridae }\end{array}$} & \multirow{2}{*}{$\begin{array}{l}\text { Orthonairovirus } \\
\text { Phlebovirus }\end{array}$} & \multirow{2}{*}{$\begin{array}{l}\text { Crimean-Congo } \\
\text { hemorrhagic fever } \\
\text { orthonairovirus } \\
\text { Rift Valley fever } \\
\text { phlebovirus }\end{array}$} & Livestock & $\begin{array}{l}\text { D or I } \\
\text { D or I }\end{array}$ & $\begin{array}{l}\text { Hyaloma spp } \\
\text { ticks }\end{array}$ & $\begin{array}{l}\text {-Serum or } \\
\text { plasma }\end{array}$ & $\begin{array}{l}\text {-IgM, IgG, PCR } \\
\text {-IgM, IgG, PCR }\end{array}$ & $\begin{array}{l}\text {-No specific treatment. Possibly } \\
\text { ribavirin for CCHFV. No } \\
\text { commercially available vaccine. }\end{array}$ \\
\hline & & & $\begin{array}{l}\text { Domestic } \\
\text { ruminants }\end{array}$ & & $\begin{array}{l}\text { Aedes and } \\
\text { Culex spp } \\
\text { mosquitoes }\end{array}$ & $\begin{array}{l}\text {-Serum or } \\
\text { plasma }\end{array}$ & & $\begin{array}{l}\text {-No specific treatment. Treat } \\
\text { symptoms. No commercially } \\
\text { available vaccine }\end{array}$ \\
\hline Flaviviridae & Flavivirus & West Nile virus & Birds & I & $\begin{array}{l}\text { Culex spp } \\
\text { mosquitoes }\end{array}$ & $\begin{array}{l}\text {-Serum } \\
\text {-CSF }\end{array}$ & $\begin{array}{l}\text {-IgM, IgG, PCR } \\
\text { - IgM, PCR, PRNT }\end{array}$ & $\begin{array}{l}\text { No specific treatment or } \\
\text { prophylaxis. Treat symptoms. }\end{array}$ \\
\hline \multirow[b]{2}{*}{ Togaviridae } & \multirow[b]{2}{*}{ Alphavirus } & \multirow[t]{2}{*}{$\begin{array}{l}\text { Chikungunya } \\
\text { virus }\end{array}$} & $\begin{array}{l}\text { Non-human } \\
\text { primates }\end{array}$ & I & $\begin{array}{l}\text { Aedes spp } \\
\text { mosquitoes }\end{array}$ & $\begin{array}{l}\text {-Serum or } \\
\text { plasma }\end{array}$ & $\begin{array}{l}\text {-IgM, IgG, Cell culture, } \\
\text { PCR, PRNT }\end{array}$ & $\begin{array}{l}\text {-No specific treatment or } \\
\text { prophylaxis. Treat symptoms. }\end{array}$ \\
\hline & & & Birds & I & $\begin{array}{l}\text { Culex spp } \\
\text { mosquitoes }\end{array}$ & $\begin{array}{l}\text {-Serum or } \\
\text { plasma }\end{array}$ & $\begin{array}{l}\text { - IgM, IgG,Cell } \\
\text { culture,PCR, PRNT }\end{array}$ & $\begin{array}{l}\text {-No specific treatment or } \\
\text { prophylaxis. Treat symptoms. }\end{array}$ \\
\hline \multirow{2}{*}{ Poxviridae } & \multirow{2}{*}{ Parapoxvirus } & \multirow[b]{2}{*}{$\begin{array}{l}\text { Pseudocowpox } \\
\text { virus }\end{array}$} & Sheep, goats & $\mathrm{D}$ & N/A & $\begin{array}{l}\text {-Biopsy } \\
\text { material, fluid } \\
\text { from lesion }\end{array}$ & $\begin{array}{l}\text {-PCR, sequencing, EM, } \\
\text { culture }\end{array}$ & $\begin{array}{l}\text {-No specific treatment. Treat } \\
\text { symptoms. }\end{array}$ \\
\hline & & & Cattle & $\mathrm{D}$ & N/A & $\begin{array}{l}\text {-Biopsy } \\
\text { material, fluid } \\
\text { from lesion }\end{array}$ & $\begin{array}{l}\text {-PCR, sequencing, EM, } \\
\text { culture }\end{array}$ & $\begin{array}{l}\text {-No specific treatment. Treat } \\
\text { symptoms. }\end{array}$ \\
\hline Hepeviridae & Orthohepevirus & Orthohepevirus A & Swine & $\mathrm{D}$ & N/A & $\begin{array}{l}\text { Serum } \\
\text { Stool }\end{array}$ & $\begin{array}{l}\text {-IgM, IgG, PCR } \\
\text { - PCR }\end{array}$ & $\begin{array}{l}\text { Acute: No specific treatment } \\
\text { Chronic: Reduce } \\
\text { immunosuppressive drugs. } \\
\text { Possibly interferon or ribavirin }\end{array}$ \\
\hline
\end{tabular}

imported cases always exists. These would include the coronaviruses, SARS and Middle East respiratory syndrome-related coronavirus (MERS), the henipahviruses with outbreaks in Australia and Malaysia, and the flaviviruses such as Dengue virus, Yellow fever virus and Zika virus, which cause considerable morbidity and mortality, as well as avian influenza viruses such as $\mathrm{H} 5 \mathrm{~N} 1$ and $\mathrm{H} 7 \mathrm{~N} 9$, which have caused outbreaks in Asia [9,13-21].

This review highlights the important zoonotic viral infections occurring in South Africa, focusing on viral infections transmitted primarily from domestic animals, wildlife and livestock.

\section{Lyssaviruses}

Rabies lyssavirus and the related lyssaviruses belong to the family Rhabdoviridae. There are several genotypes with different strains in some of the genotypes [10,22]. Table 2 shows the species found in South Africa.

Rabies is an ancient disease and affects most mammals [10]. It is endemic in many parts of the world, including certain provinces in South Africa, where dog bite injury consultations are high in both the private and public sectors [23]. Epidemics are usually associated with climatic or environmental events which result in an increase in potential hosts. This results in the so called "re-emergences" [10].

There are two distinct biotypes of rabies virus in southern Africa, making the epidemiology more complex. The canid biotype cycles in carnivores of the family Canidae (dogs, jackals, bat-eared foxes, plus others), whereas the mongoose biotype cycles in carnivores of the Herpestidae family [24]. Since the late 1970s, most human rabies cases have followed bites from infected dogs in KwaZulu-Natal [25], but in the last 10 years, additional provinces have been affected, including the Mpumalanga, Limpopo, Eastern Cape, North West and Free State provinces [26]. Between 1983 and 2015, there have been over 400 laboratory-confirmed human rabies cases in South Africa [26,27].

Typical furious rabies presents as encephalitis, often with characteristic features such as photophobia and hydrophobia. However, it is difficult to diagnose clinically, and it has a broad spectrum of differential diagnoses [23]. The diagnosis can be confirmed through testing antemortem and post-mortem specimens (Table 1), although testing is often inconclusive. An intermittent pattern of virus shedding in saliva mandates testing of multiple specimens, while tests on cerebrospinal fluid are not sensitive [23].

Rabies kills more than 50000 people annually, mostly in developing countries, and mostly due to bites, scratches or mucosal exposures from infected dogs $[10,25]$. It is an invariably fatal disease, but it is completely preventable with the use of rabies post-exposure prophylaxis (PEP) in patients exposed to potential (or confirmed) rabid animals. Exposures are categorized based on the risk of the exposure as category 1, 2 or 3 (Table 3) [26].

The other rabies-related lyssaviruses include Lagos bat lyssavirus (LBV), Mokola lyssavirus (MOKV), Duvenhage lyssavirus (DUVV), European bat 1 lyssavirus and European bat 2 lyssavirus, and Australian 
Table 2. Lyssaviruses in South Africa

\begin{tabular}{|l|l|l|}
\hline Species & $\begin{array}{l}\text { Zoonotic } \\
\text { potential }\end{array}$ & Potential vertebrate hosts \\
\hline Rabies lyssavirus & Yes & $\begin{array}{l}\text { *Dogs, cats, bat-eared foxes, black-backed jackals, } \\
\text { mongooses, caracals, leopards, bats }\end{array}$ \\
\hline $\begin{array}{l}\text { Lagos bat } \\
\text { lyssavirus }\end{array}$ & No & Fruit bats, cats, mongooses, dogs \\
\hline Mokola lyssavirus & Yes & Cats \\
\hline $\begin{array}{l}\text { Duvenhage } \\
\text { lyssavirus }\end{array}$ & Yes & Insectivorous bats \\
\hline $\begin{array}{l}\text { *Canine strain of rabies virus well adapted to dogs, jackals, and bat-eared foxes, but not to } \\
\text { humans, cats, and other species, and therefore does not usually spread within these species. }\end{array}$ \\
\hline
\end{tabular}

Table 3. Post-exposure prophylaxis for rabies prevention

\begin{tabular}{|l|l|}
\hline Risk category & Management \\
\hline $\begin{array}{l}1 \text {-Touching or feeding animal, licking of } \\
\text { intact skin }\end{array}$ & $\begin{array}{l}\text { If case history is reliable, no further } \\
\text { management necessary. } \\
\text { If history not reliable, treat as category 2. }\end{array}$ \\
\hline $\begin{array}{l}\text { 2 - Nibbling of skin, superficial scratch but } \\
\text { no bleeding }\end{array}$ & $\begin{array}{l}\text { Wound treatment - Flush with soap and } \\
\text { water for at least 5 minutes and apply } \\
\text { disinfectant (e.g. iodine solution) and } \\
\text { avoid suturing. Administer anti-tetanus and } \\
\text { antibiotics if indicated. } \\
\text { *Administer vaccine. Stop vaccine schedule } \\
\text { if animal rabies-negative on laboratory } \\
\text { testing or remains well after 10 days. } \\
\text { Do not administer rabies immune globulin } \\
\text { (RIG), unless highly immunosuppressed. }\end{array}$ \\
\hline $\begin{array}{l}\text { 3 - Bites/scratches which penetrate skin and } \\
\text { draw blood, licking of mucous membranes } \\
\text { or broken skin }\end{array}$ & $\begin{array}{l}\text { Wound treatment (as above). } \\
\text { *Administer vaccine. Stop vaccine schedule } \\
\text { if animal rabies-negative on laboratory } \\
\text { testing or remains well after 10 days. } \\
\text { Administer RIG. }\end{array}$ \\
\hline $\begin{array}{l}\text { *Vaccine schedule in South Africa - reduced four-dose schedule. Administer vaccine } \\
\text { on days 0, 3, 7 and } 14 . \text { A } 5^{\text {th }} \text { dose at 28 days } \\
\text { patients. }\end{array}$ & \begin{tabular}{l} 
may be included for immunosuppressed \\
\hline
\end{tabular}
\end{tabular}

bat lyssavirus. Of these, 3 are found in Africa, namely LBV, MOKV and DUVV.

MOKV has been isolated from terrestrial animals but not from bats, whereas LBV and DUVV are thought to be bat viruses. DUVV and MOKV, but not LBV, have been responsible for rare zoonotic events $[22,28,29]$. LBV has been isolated from fruit bats and a cat in KwaZulu-Natal. MOKV has been isolated from cats in KwaZuluNatal and the Eastern Cape. DUVV was discovered in 1970, when a person bitten by an insectivorous bat died of a rabies-like disease in the Gauteng province [22].

\section{Haemorrhagic fever viruses}

Viral haemorrhagic fevers (VHFs) are severe viral infections, with most a result of zoonoses, and may present with a variable clinical course [30]. The recent outbreak of Ebolavirus in West Africa, for which the discovery of the reservoir host remains elusive, highlights the importance of research into zoonotic infections, since the public health impact may be devastating [31,32]. Many of VHFs, including Ebolavirus, are not endemic in South Africa [33]. However, two of the viral haemorrhagic fevers, Crimean-Congo haemorrhagic fever orthonairovirus (CCHFV) and Rift Valley fever phlebovirus (RVFV) are endemic in South Africa [34].

\section{Crimean-congo haemorrhagic fever orthonairovirus}

CCHFV is a tick-borne nairovirus of the Nairoviridae family, causing asymptomatic viremia in farm animals [30]. The principal vectors are ticks of the Hyaloma species (Figure 1), resulting in a predominantly indirect zoonoses. However, transmission may also result from direct contact with infected tissues.

CCHFV occurs sporadically in South Africa, with an average of 5 to 6 cases confirmed each year since 1981 [35]. Most cases are isolated, but there were cases of nosocomial spread in the 1980s [36]. Most of cases report exposure to ticks, with the remainder assumed to have been exposed to infected tissues or blood, and infected persons are usually farmers, farm workers or veterinary professionals [37].

Incubation periods vary according to the mode of transmission. Following a tick bite, it ranges from 1-5 days and following contact with infected blood/tissues it usually ranges 5-7 days, with a maximum of 13 days $[38,39]$. CCHFV usually presents with sudden onset of fever, rigors, severe headache, myalgia and intense backache $[30,39]$. The Swanepoel criteria, which includes both clinical and laboratory parameters for the clinical diagnosis of CCHFV, is still used today [40]. Laboratory diagnosis relies on serology and PCR, whilst clinical pathology parameters will show a leukopenia, decreasing platelet count, increasing transaminases and coagulation abnormalities [38,41]. Severe haemorrhage may occur on day four or five of the illness [42]. Multiple mechanisms contribute to haemorrhage, and includes endothelial damage, thrombocytopenia and liver damage.

Treatment is generally supportive, but there have been case reports showing anecdotal success with the antiviral agent ribavirin. Case fatality rates are as high as $30 \%$.

\section{Rift valley fever phlebovirus}

RVFV is a viral zoonosis, also endemic in South Africa, which primarily affects domestic ruminants, often resulting in large epizootics [42]. In 2008 there was a re-emergence of RVFV in South Africa, with five provinces affected, the Eastern Cape, Gauteng, Limpopo, Mpumalanga and North West [42].

Transmission to humans occurs predominantly through contact with infected animal tissues and less commonly through mosquito bites $[39,42]$. Infection in humans is typically asymptomatic or may cause mild fever, with an incubation period of 2-6 days [39]. The laboratory testing for RVFV includes serology and PCR [34,41]. Complications

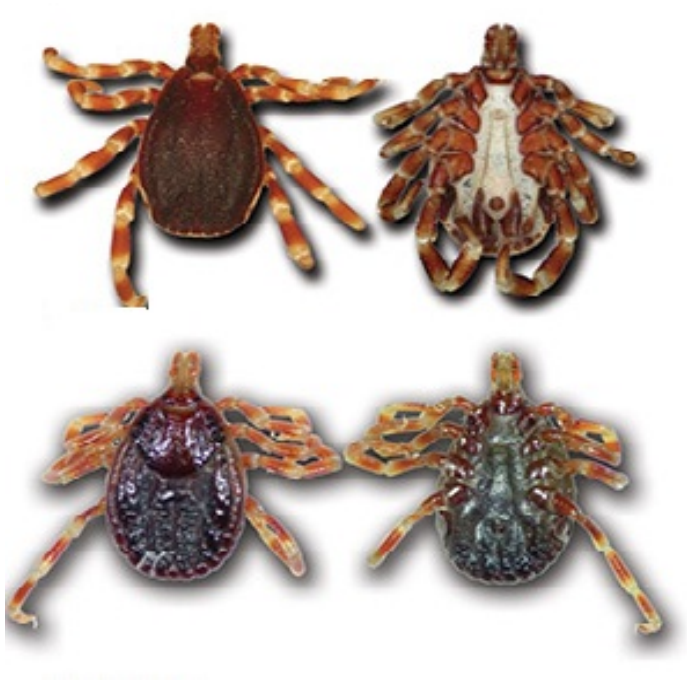

Figure 1. Example of a Hyaloma spp tick

Adapted from http://www.afrivip.org/sites/default/files/Ticks_identification/ixod_hyal. $\mathrm{html}$ licensed under Creative Commons Attribution license 
are rare, with haemorrhagic fever and ocular complications occurring in less than $1 \%$ of cases $[39,42]$. Treatment is supportive in nature.

\section{Flaviviruses}

Most members of the genus Flavivirus in the family Flaviviridae are arboviruses, transmitted by arthropods, particularly mosquitoes or ticks [43]. Although numerous zoonotic flaviviruses are found worldwide, only West Nile virus (WNV) is frequently found in South Africa. This being said, the risk of imported cases of other flaviviruses such as Dengue virus and Yellow fever virus always exists, since they are endemic in many African countries.

\section{West nile virus}

WNV is transmitted by mosquitoes of the Culex spp. and is a reemerging pathogen of global concern, distributed throughout Africa, the Middle East, Asia, parts of Europe, Australia, North and South America, and the Caribbean [44]. In South Africa, one of the largestever recorded outbreaks of WNV infection occurred in 1974 in the semi-desert region of the Karoo, followed by an epizootic involving WNV and Sindbis virus (SINV) in the Gauteng province in the 1980s [44-46]. Since then, there have been 5-15 confirmed human cases per year, although only a small proportion of cases are subject to laboratory confirmation [45].

Transmission of WNV involves birds, the main amplifying hosts and ornithophilic mosquitoes as maintenance vectors, while humans and horses are incidental hosts [45,47].

There are two major lineages of WNV, lineages 1 and 2, with lineage 2 being endemic in southern Africa. Recently, though, additional lineages have been reported in other parts of the world.

Most WNV infections are asymptomatic, although fever with rash, arthralgia, and myalgia occurs in approximately $20 \%$ of cases. Severe disease occurs in about $1 \%$ of cases, and includes encephalitis, meningitis and acute flaccid paralysis $[45,48]$.

Detection of IgM in serum or CSF is the preferred method of diagnosis. Positive results should always be confirmed by virus neutralisation assays because of the inherent problem of cross-reactivity [44]. Although PCR and virus isolation can detect early infection, these techniques have generally only been successful in diagnosing advanced disease [49].

As no specific antiviral exists for the treatment of WNV, management is aimed at alleviating the symptoms.

\section{Dengue virus}

The flaviviruses Dengue virus and Yellow fever virus are endemic in many tropical countries around the world. Neither is endemic in South Africa, but in 1926 a confirmed dengue outbreak, with local transmission, occurred in Durban, with occasional sporadic cases reported in returning travellers from areas of endemicity [50]. From 2008 to 2013, 83 acute dengue infections were identified through laboratory-based surveillance, showing that, although not endemic in South Africa, dengue virus is nevertheless an important zoonotic infection, albeit due to imported cases [50].

Dengue virus is transmitted by the bite of an Aedes spp mosquito and, after an incubation period of 2-7 days, an acute onset of fever, headache, arthralgia, retro-orbital pain, gastrointestinal symptoms and rash may follow [18,51].
The four dengue virus serotypes are maintained in forested areas by a transmission cycle between non-human primates and Aedes mosquitoes, with Aedes aegypti, which is widely distributed in Africa and is adapted to breeding in proximity to human populations, the usual vector [50].

Infection with one type of dengue virus gives little or no protection against infection with another type. In fact, infection with a second type of dengue virus, after initial infection with a different type, predisposes to the most severe complication of dengue fever, namely dengue haemorrhagic fever/dengue shock syndrome (DHF/DSS), the pathogenesis of which is purportedly due to an immune-enhancement phenomenon.

As for other arboviruses in South Africa, laboratory diagnosis takes place at the Special Viral Pathogens Laboratory at the Centre for Emerging and Zoonotic Diseases, National Institute for Communicable Diseases (NICD). The testing protocol includes screening with a haemagglutination inhibition assay (HAI), following which reactive specimens are tested for virus-specific IgM using a reverse capture enzyme linked immunosorbent assay (ELISA). PCR and virus isolation are also attempted in acute cases. A positive IgM in paired sera, or a 4 -fold rise in IgG titre in paired sera, confirms the diagnosis, as does a positive PCR or viral culture [50].

Since there are no curative therapies for dengue fever, preventative measures such as vector control, as well as the use of the recently licenced dengue vaccine (Dengvaxia), is important. Management of confirmed cases involves treating the symptoms [52].

\section{Alphaviruses}

The genus Alphavirus of the family Togaviridae contains 31 species, with two of them known to cause disease in South Africa, Chikungunya virus (CHIKV) and Sindbis virus (SINV).

\section{Chikungunya virus}

Human outbreaks of CHIKV infection have occurred in the eastern Northern Province, while an epizootic in monkeys without human cases occurred in northern KwaZulu-Natal in 1964 [53]. Certain nonhuman primates serve as the primary host. Transmission between female Aedes spp. mosquitoes (Fig. 2) and primates occurs at night, while humans may be bitten in the vicinity of wild-primate sleeping places [53].

CHIKV infection traditionally results in a febrile illness and rash, with the hallmark feature being a debilitating arthralgia that primarily affects the peripheral joints $[54,55]$.

Most cases are symptomatic, albeit non-fatal and self-limiting. Rare manifestations of CHIKV include conjunctivitis, encephalitis and haemorrhagic fever.

Fibroblasts are the main cell type infected and therefore tropism is for muscle, joints, skin and connective tissues, although pathogenesis is poorly understood.

Laboratory diagnosis of CHIKV involves serology (IgM and IgG) and cell culture of plasma or serum, as well as PCR on serum specimens. Positive serology should always be confirmed with a plaque reduction neutralisation test (PRNT) because of the low specificity of serology.

Treatment aims at managing the symptoms with anti-pyretics, analgesics and anti-inflammatory agents. For chronic cases of arthritis 
due to CHIKV, chloroquine phosphate was shown to provide some relief in those not responding to non-steroidal anti-inflammatory drugs [56].

\section{Sindbis virus}

SINV circulates in transmission cycles between pastoral birds and ornithophilic mosquitoes and may occasionally be transmitted to humans, who are poorly viremic after infection and thus are deadend hosts [53,57]. The Culex spp. mosquitoes are the main vectors, resulting in human infection across the central plateau of South Africa, usually in summer. Affected provinces include Gauteng, Free State, and Northern Cape [57]. Sporadic cases have also been reported from the Mpumalanga, North West, Eastern Cape, Western Cape and KwaZulu-Natal provinces of South Africa [58]. SINV and WNV may co-circulate and cause outbreaks at the same time, since they both use Culex mosquito vectors. This phenomenon of dual outbreaks has been documented numerous times in South Africa: across the Highveld in 1967 and again in 1984, and in the Karoo (Northern Cape and Free State provinces) in 1974 and 1976 [59].

Sindbis fever is usually mild with spontaneous resolution. Symptoms include fever, rash, headache, arthralgia, myalgia and fatigue [57]. Occasionally arthritis may persist for months or years [60]. Laboratory diagnosis includes serology, specifically IgM antibodies, and PCR and viral isolation, which are only performed in acute cases owing to the short period of viraemia. As with CHIKV, treatment is aimed at improving symptoms.

\section{Poxviruses}

Viruses of the Poxviridae family are the largest viruses known to infect humans. The genera containing species which may infect humans include Orthopoxvirus, Parapoxvirus, Molluscipoxvirus and Yatapoxvirus, all belonging to the subfamily Chordopoxvirinae [61]. Some of these poxviruses have zoonotic potential, and cases have been reported in South Africa, albeit very rarely [62].

Orf virus, a parapoxvirus, is found worldwide and is acquired through direct contact with infected farm animals or their products. In addition, the virus has been isolated from fomites such as fences, barn doors, feeding troughs and shears [63]. It is the causal agent of papular dermatitis in sheep and goats, and it is generally accepted that it is endemic in South Africa, with higher incidence during the rainy season [62]. Scratching scabs off infected animals, as well as treating them with oil, are considered risk factors for zoonotic transmission to farmers [62].

Pseudocowpox virus, the other parapoxvirus able to infect humans, has also been identified as a zoonosis in South African veterinarians [64]. However, both orf and pseudocowpox infections are neglected zoonoses, and are likely to be under-recognised by medical practitioners.

Both these viruses may cause painful lesions on the hands, fingers (Figures 2 and 3) and face, with associated lymphadenopathy [63], and symptoms may last for 6 to 24 weeks $[62,63]$. Complications include atypical proliferating forms of giant orf in immunocompromised individuals, as well as milder complications such as erythema multiforme, bullous pemphigoid, swan neck deformities and paraesthesia [65-68].

Diagnosis of Parapoxvirus infection involves PCR and sequencing, while older methods include electron microscopy and tissue culture [62].

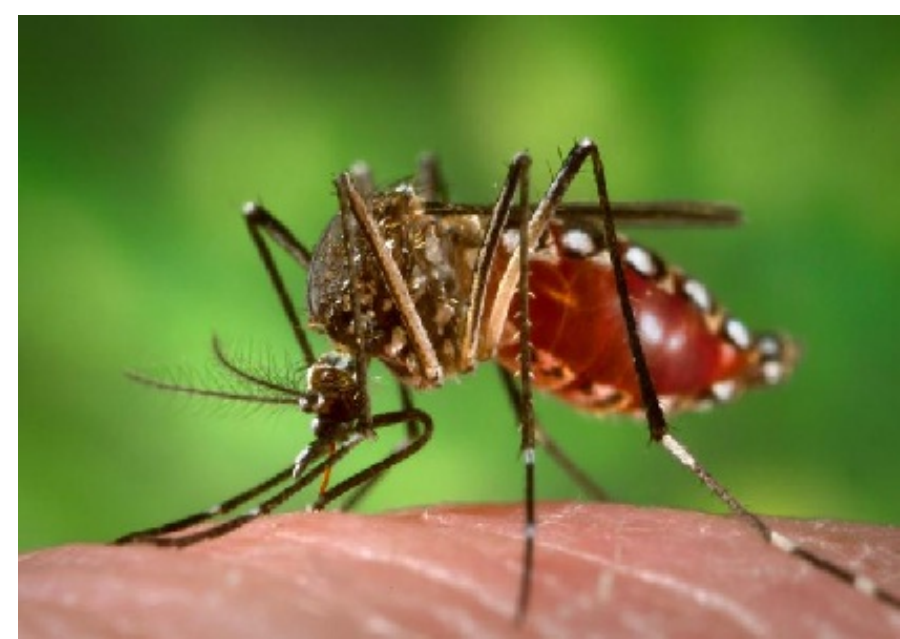

Figure 2. Aedes aegypti mosquito

Courtesy of the United States Department of Health and Human Services - http://phil.cdc gov/phil/home.asp

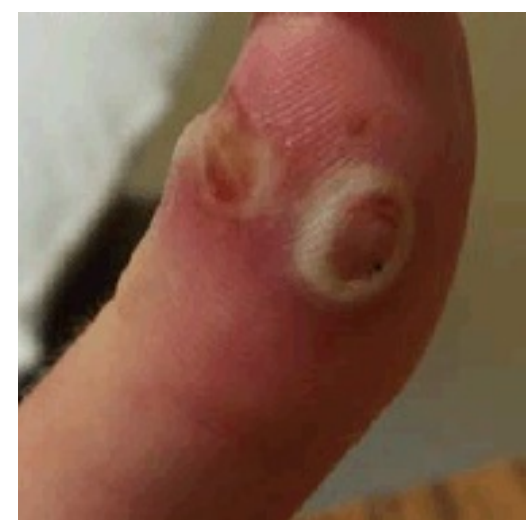

Figure 3. Typical Orf virus lesion with eroded vesicles on an erythematous base and white halo Courtesy CDC - http://www.cdc.gov/mmwr/preview/mmwrhtml/mm5503a1.htm

Fundamental to the management of such cases is early and correct diagnosis, which not only serves to avoid unnecessary antibiotic therapy or hospitalisation but will also alleviate the patients' anxiety.

Other poxviruses with zoonotic potential include Monkeypox virus and Cowpox virus, both belonging to the genus Orthopoxvirus. Although not endemic in South Africa, having an awareness of them is important in order to recognise imported cases, which may resemble other poxvirus infections.

Cowpox was previously thought to be enzootic in cattle, but most human cases occur without contact with farm animals. The virus was subsequently isolated from domestic cats in 1978. Infection is usually acquired through contact with infected cats, while the primary reservoir is thought to be rodents [69].

Human monkeypox is a rare viral zoonosis endemic in central and western Africa, with its natural reservoir unknown. As with cowpox, it is thought that rodents may be involved in transmission to humans [70].

\section{Orthohepevirus}

Orthohepevirus A, the causative agent of hepatitis E, of the family Hepeviridae, is an important pathogen with a worldwide distribution, which is primarily transmitted via the faecal-oral route, unlike the other endemic zoonotic infections presented here, whose primary mode of 
transmission is zoonotic in nature. However, many animal species are infected by variants of orthohepevirus, and it is a swine virus that is most capable of causing a zoonotic form of hepatitis E, which may be transmitted by consumption of contaminated meat [71]. In South Africa, the seroprevalence of anti-hepatitis $\mathrm{E}$ antibodies ranges from $6.6 \%$ to $15.3 \%$, with rural areas having the highest prevalence [72]. In a recent study in the Western Cape however, the seroprevalence was determined to be as high as $28 \%$ [73].

Hepatitis E usually presents as a self-limiting acute infection, very rarely resulting in fulminant hepatitis, with pregnancy being a risk factor. Chronic hepatitis E may occur in patients who are heavily immunosuppressed, usually transplant patients. Clinical features of acute infection include jaundice accompanied by nausea, vomiting, abdominal pain, fever and hepatomegaly. Less common symptoms include diarrhoea, arthralgia, pruritis and urticarial rash.

A combination of serological and molecular tests is used for the laboratory diagnosis. Serology is usually negative in the first week after infection, but antibodies become detectable a few days after disease onset.

There is no specific treatment for acute infection. Chronic infection in transplant patients requires reduction in the dose of immunosuppressive drugs, with or without treatment with interferon or ribavirin.

\section{Conclusion}

Zoonotic viral infections are of public health concern globally. There are numerous examples throughout human history of zoonotic infections causing considerable morbidity and mortality. The source of zoonotic infections may be wild animals, pets or farmed animals and, with the latter set to increase as the human population expands, zoonotic viral infections will always be a public health concern. It is important that medical practitioners have some knowledge of their local zoonotic viral infections. This will allow for appropriate management of these diseases, most of which are often neglected. The One Health Program established in 2014 by the South Africa Regional Global Disease Detection Center should provide assistance to the National Department of Health, by strengthening the coordination of activities around the human and animal interface and expanding zoonotic disease surveillance across sectors.

\section{Funding}

This review article did not receive any specific grant from funding agencies in the public, commercial, or not-for-profit sectors.

\section{Competing Interests}

We hereby declare that there is no conflict of interest.

\section{Acknowledgements}

HN initiated the writing of this article. HN and SA wrote and revised the manuscript.

\section{References}

1. Taylor LH, Latham SM, Woolhouse ME (2001) Risk factors for human disease emergence. Philos Trans R Soc Lond B Biol Sci 356: 983-989. [Crossref]

2. Kruse H, kirkemo AM, Handeland K (2004) Wildlife as source of zoonotic infections. Emerg Infect Dis 10: 2067-2072. [Crossref]

3. Bekker JL, Hoffman LC, Jooste PJ (2012) Wildlife-associated zoonotic diseases in some southern African countries in relation to game meat safety: a review. Onderstepoort $J$ Vet Res 79: E1-1E12. [Crossref]
4. Weyer J, Mulumba M (2017) One Health in South Africa? South Afr J Infect Dis 32 4-5.

5. Gibbs EP (2014) The evolution of One Health: a decade of progress and challenges for the future. Vet Rec 174: 85-91. [Crossref]

6. Osorio JE, Yuill TM. Zoonoses (2008) In: Mahy B, van Regenmortel M, editors Encyclopedia of Virology 3rd ed. Elsevier Academic Press 383-397.

7. Manojkumar R, Mrudula V (2006) Emerging viral diseases of zoonotic importancereview. Int J Tropic Med 1: 162-166.

8. Venkatesan G, Balamurugan V, Gandhale PN (2010) Asian J Anim Vet Adv 5: 77-92.

9. Weese JS (2002) A review of equine zoonotic diseases: Risks in veterinary medicine. In: Proceedings of the Annual Convention of the AAEP.

10. Bengis RG, Leighton FA, Fischer JR, Artois M, Mörner T, et al. (2004) The role of wildlife in emerging and re-emerging zoonoses. Rev Sci Tech 23: 497-511. [Crossref]

11. Murphy FA (1998) Emerging zoonoses. Emerg Infect Dis 4: 429-435. [Crossref]

12. Ludwig B, Kraus FB, Allwinn R, Doerr HW, Preiser W (2003) Viral zoonoses - a threat under control? Intervirology 46: 71-78. [Crossref]

13. Tai DY (2006) SARS: how to manage future outbreaks? Ann Acad Med Singapore 35 368-373. [Crossref]

14. To KK, Hung IF, Chan JF, Yuen KY (2013) From SARS coronavirus to novel anima and human coronaviruses. J Thorac Dis 5 Suppl 2: S103-108. [Crossref]

15. Peiris JS, Poon LL (2008) Detection of SARS coronavirus in humans and animals by conventional and quantitative (real time) reverse transcription polymerase chain reactions. Methods Mol Biol 454: 61-72. [Crossref]

16. Memish ZA, Mishra N, Olival KJ, Fagbo SF, Kapoor V, et al. (2013) Middle East respiratory syndrome coronavirus in bats, Saudi Arabia. Emerg Infect Dis 19: 18191823. [Crossref]

17. Lam SK, Chua KB (2002) Nipah virus encephalitis outbreak in Malaysia. Clin Infect Dis 34 Suppl 2: S48-51. [Crossref]

18. Gubler DJ (1998) Dengue and dengue hemorrhagic fever. Clin Microbiol Rev 11: 480496. [Crossref]

19. Swayne DE, King DJ (2003) Avian influenza and Newcastle disease. J Am Vet Med Assoc 222: 1534-1540. [Crossref]

20. de Jong MD, Hien TT (2006) Avian influenza A (H5N1). J Clin Virol 35: 2-13. [Crossref]

21. Lai KY, Ng GW, Wong KF, et al. (2013) Human H7N9 avian influenza virus infection: a review and pandemic risk assessment. Emerg Microbes Infect 2: e48. [Crossref]

22. Paweska JT, Blumberg LH, Liebenberg C, Hewlett RH, Grobbelaar AA, et al. (2006) Fatal human infection with rabies-related Duvenhage virus, South Africa. Emerg Infect Dis 12: 1965-1967.

23. National Institute for Communicable Diseases. Rabies. Communicable Diseases Communiqué, Centre for Emerging and Zoonotic Diseases. 2014; 13: 4.

24. Sabeta CT, Bingham J, Nel LH (2003) Molecular epidemiology of canid rabies in Zimbabwe and South Africa. Virus Res 91: 203-211. [Crossref]

25. Cohen C, Sartorius B, Sabeta C, Zulu G, Paweska J, et al. (2007) Epidemiology and molecular virus characterisation of re-emerging rabies, South Africa. Emerg Infect Dis 13: 1879-1886. [Crossref]

26. National Institute for Communicable Diseases (2016) Rabies update and review of human cases. Communicable Diseases Communiqué, Centre for Emerging and Zoonotic Diseases 15: 1983-2015.

27. Bishop GC, Durrheim DN, Kloeck PE, Godlonton JD, Bingham J, et al. (2010) Rabies guide for the medical, veterinary and allied professionals. Department of Agriculture and Department of Health, South Africa.

28. Markotter W, Randles J, Rupprecht CE, Sabeta CT, Taylor PJ, et al. (2006) Lagos bat virus, South Africa. Emerg Infect Dis 12: 504-506. [Crossref]

29. Von Teichman BF, de Koker WC, Bosch SJ, Bishop GC, Meredith CD, et al. (1998) Mokola virus infection: description of recent South African cases and a review of the virus epidemiology. J S Afr Vet Assoc 69: 169-171.

30. Bannister B (2010) Viral haemorrhagic fevers imported into non-endemic countries: risk assessment and management. Br Med Bull 95: 193-225. [Crossref] 
31. Schieffelin JS, Shaffer JG, Goba A, Gbakie M, Gire SK, et al. (2014) Clinical illness and outcomes in patients with Ebola in Sierra Leone. N Engl J Med 371: 2092-2100. [Crossref]

32. Peters CJ, LeDuc JW (1999) An introduction to Ebola: the virus and the disease. $J$ Infect Dis 179 Suppl 1: ix-xvi. [Crossref]

33. Gear JH (1989) Clinical aspects of African viral hemorrhagic fevers. Rev Infect Dis 11 Suppl 4: S777-782. [Crossref]

34. National Institute for Communicable Diseases. Healthcare Workers Guidelines on Rift Valley fever. 2011

35. National Institute for Communicable Diseases (2017) Crimean-Congo haemorrhagic fever. Communicable Diseases Communiqué, Centre for Emerging and Zoonotic Diseases. 16: 2.

36. Van Eeden PJ, Van Eeden SF, Joubert JR, King JB, van de Wal BW, et al. (1985) A Nosocomial Outbreak of Crimean-Congo Haemorrhagic Fever at Tygerberg Hospital. Part II. Mangement of patients. S Afr Med J 68: 711-717.

37. Msimang V, Weyer J, Leman P (2013) Update: Crimean-Congo haemorrhagic fever in South Africa. Communicable Diseases Surveillance Bulletin, Centre for Emerging and Zoonotic Diseases, NICD 11: 62-64.

38. National Institute for Communicable Diseases (2014) Focus Feature: Crimean-Congo haemorrhagic fever (CCHF). Communicable Diseases Communiqué, Centre for Emerging and Zoonotic Diseases. 13: 3-6.

39. Swanepoel R, Burt F (2009) Bunyaviridae. In: Zuckerman A, Banatvala J, Schoub B, et al, editors. Principles and Practice of Clinical Virology. 6th ed. Chichester: John Wiley \& Sons Ltd 897-938.

40. Swanepoel R, Shepherd AJ, Leman PA, Shepherd SP, McGillivray GM, et al. (1987) Epidemiologic and clinical features of Crimean-Congo hemorrhagic fever in southern Africa. Am J Trop Med Hyg 36: 120-132. [Crossref]

41. National Department of Health, South Africa. National guidelines for the recognition and management of viral haemorrhagic fevers 2014.

42. Archer BN, Weyer J, Paweska J, Nkosi D, Leman P, et al. (2011) Outbreak of Rif Valley fever affecting veterinarians and farmers in South Africa, 2008. S Afr Med J 101: 263-266. [Crossref]

43. Schoub BD, Venter MF (2009) In: Zuckerman A, Banatvala J, Schoub B, et al, editors. Principles and Practice of Clinical Virology. 6th ed. Chichester: John Wiley \& Sons Ltd 897-938.

44. Zaayman D, Venter M (2012) West Nile virus neurologic disease in humans, South Africa, September 2008-may 2009. Emerg Infect Dis 18: 2051-2054. [Crossref]

45. Venter M, Human S, Zaayman D, Gerdes GH, Williams J, et al. (2009) Lineage 2 west nile virus as cause of fatal neurologic disease in horses, South Africa. Emerg Infect Dis 15: 877-884. [Crossref]

46. McIntosh BM, Jupp PG (1976) Epidemics of West Nile and Sindbis viruses in South Africa with Culex (Culex) univittatus Theobald as vector. S Afr J Sci 72: 295-300.

47. Reed KD, Meece JK, Henkel JS, Shukla SK (2003) Birds, migration and emerging zoonoses: west nile virus, lyme disease, influenza A and enteropathogens. Clin Med Res 1: 5-12. [Crossref]

48. Kulasekera VL, Kramer L, Nasci RS, Mostashari F, Cherry B, et al. (2001) West Nile virus infection in mosquitoes, birds, horses, and humans, Staten Island, New York, 2000. Emerg Infect Dis 7: 722-725.

49. Sampathkumar P (2003) West Nile virus: epidemiology, clinical presentation, diagnosis, and prevention. Mayo Clin Proc 78: 1137-1144. [Crossref]

50. Msimang V, Weyer J, le Roux C, Leman P, Kemp A, et al. (2013) Dengue fever in South Africa: an imported disease. Communicable Diseases Surveillance Bulletin, Centre for Emerging and Zoonotic Diseases, NICD. 11: 58-62.

51. Prinsloo B (2006) Arboviral diseases in southern Africa. SA Fam Pract 48: 25-28.
52. Aguiar M, Stollenwerk N, Halstead SB (2016) The Impact of the Newly Licensed Dengue Vaccine in Endemic Countries. PLoS Negl Trop Dis 10: e0005179. [Crossref]

53. Jupp PG (2005) Mosquitoes as vectors of human disease in South Africa. SA Fam Pract 47:68-72.

54. Powers AM, Logue $\mathrm{CH}$ (2007) Changing patterns of chikungunya virus: re-emergence of a zoonotic arbovirus. J Gen Virol 88: 2363-2377. [Crossref]

55. Morens DM, Fauci AS (2014) Chikungunya at the door--déjà vu all over again? N Engl J Med 371: 885-887. [Crossref]

56. Brighton SW (1984) Chloroquine phosphate treatment of chronic Chikungunya arthritis. An open pilot study. S Afr Med J 66: 217-218. [Crossref]

57. Storm N, Weyer J, Markotter W, Kemp A, Leman PA, et al. (2014) Human cases of Sindbis fever in South Africa, 2006-2010. Epidemiol Infect 142: 234-238. [Crossref]

58. Storm N, Weyer J, Markotter W, Leman P, Kemp A, et al. (2013) Phylogeny of sindbis virus isolates from South Africa. South Afr J Epidemiol Infect 28: 207-214.

59. National Institute for Communicable Diseases (2014) Focus Feature: Sindbis fever Communicable Diseases Communiqué, Centre for Emerging and Zoonotic Diseases. 13: $2-4$.

60. Kurkela S, Manni T, Myllynen J, Vaheri A, Vapalahti O (2005) Clinical and laboratory manifestations of Sindbis virus infection: prospective study, Finland, 2002-2003. J Infect Dis 191: 1820-1829.

61. Stanford MM, McFadden G, Karupiah G, Chaudhri G (2007) Immunopathogenesis of poxvirus infections: forecasting the impending storm. Immunol Cell Biol 85: 93-102. [Crossref]

62. Scagliarini A, Piovesana S, Turrini F, Savini F, Sithole F, et al. (2012) Orf in South Africa: endemic but neglected. Onderstepoort J Vet Res 79: E1-8. [Crossref]

63. Maki A Jr, Hinsberg A, Percheson P, Marshall DG (1988) Orf: contagious pustula dermatitis. CMAJ 139: 971-972. [Crossref]

64. Gummow B (2003) A survey of zoonotic diseases contracted by South African veterinarians. J S Afr Vet Assoc 74: 72-76. [Crossref]

65. Rogers M, Bale P, De Silva LM, Glasson MJ, Collins E (1989) Giant parapox infection in a two year old child. Australas J Dermatol 30: 87-91. [Crossref]

66. Ara M, Zaballos P, Sánchez M, Querol I, Zubiri ML, et al. (2008) Giant and recurrent orf virus infection in a renal transplant recipient treated with imiquimod. $J$ Am Acad Dermatol 58: S39-40. [Crossref]

67. Ledermen ER, Green GM, De Groot HE, Dahl P, Goldman E, et al. (2007) Progressive orf virus infection in a patient with lymphoma: successful treatment using imiquimod. Clin Infect Dis 44: e100-e103. [Crossref]

68. White KP, Zedek DC, White WL, Simpson EL, Hester E, et al. (2008) Orf-induced immunobullous disease: A distinct autoimmune blistering disorder. $J$ Am Acad Dermatol 58: 49-55. [Crossref]

69. O'Connor GM, Thiru AA, Caul OE (1990) Ocular cowpox: transmission from the domestic cat to man. Br J Ophthalmol 74: 245-246. [Crossref]

70. Di Giulio DB, Eckburg PB (2004) Human monkeypox: an emerging zoonosis. Lancet Infect Dis 4: 15-25. [Crossref]

71. Goens SD, Perdue ML (2004) Hepatitis E viruses in humans and animals. Anim Health Res Rev 5: 145-156. [Crossref]

72. Tucker TJ, Kirsch RE, Louw SJ, Isaacs S, Kannemeyer J, et al. (1996) Hepatitis E in South Africa: evidence for sporadic spread and increased seroprevalence in rural areas. J Med Virol 50: 117-119. [Crossref]

73. Madden RG, Wallace S, Sonderup M, Korsman S, Chivese T, et al. (2016) Hepatitis E virus: Western Cape, South Africa. World J Gastroenterol 22: 9853-9859. [Crossref]

Copyright: ( 2018 Newmana H. This is an open-access article distributed under the terms of the Creative Commons Attribution License, which permits unrestricted use, distribution, and reproduction in any medium, provided the original author and source are credited. 